\title{
RELIGIOUS PLURALISM AND VALUE PLURALISM: RITUAL AND THE ANEGEMENT OF INTERCULTURAL DIVERSITY
}

Joel Robbins ${ }^{l}$

I am grateful for the opportunity to be able to present this talk at a meeting on the theme of "Pluralism and Interculturality: Flows and Religious Itineraries." The topic is a timely and important one in a world where a heightened concern with the public role of religion is rooted in, among other things, a realization that almost everywhere more than one religion is vying for the chance to influence social and political life. But I should confess at the outset that where religious pluralism is concerned, I feel myself to be at something of a comparative disadvantage in present company. In the introduction to a 1995 volume of essays that took on the relationship between ritual and pluralism, one of my key themes here, Jan Platvoet and Karel van der Toorn (1995: 10) note that Brazil "may serve, as perhaps no other [society], as a laboratory for the study of plurality and pluralism." Discussions of the nature of religious pluralism, the way it is lived out by religious practitioners, and the problems it raises for social scientific analysis are arguably more developed in scholarship in and about Brazil than in any other body of literature. As a scholar of global Pentecostalism, I have been stimulated by a good deal of this scholarship, but I know that what I have read is only the tip of a huge iceberg of important literature, much of it more conceptually sharp than my own present work on this subject, which is at a very early stage of development. I fear, then, that in talking about religious pluralism here today, I run the risk of not only of carrying coals to Newcastle, but of carrying coals of a quality decidedly inferior to the local varieties as well.

Faced with what I am quite sure is a justified sense of inferiority in my understanding of the contemporary literature on religious diversity, I am going to rely on two time honored scholarly strategies for maneuvering out of tight spots of this kind. One of these is quite general in nature and involves somewhat subtly changing the subject in ways that bring it on to ground I have some experience in covering. I deploy this strategy here by shifting our focus first from religious pluralism as it is most often understood to value pluralism, which I want to suggest ought to be seen as a closely

\footnotetext{
${ }^{1}$ University of Cambridge Professor - Contact: jlrobins@ucsd.edu
} 
related issue, and also by directing our attention away from religion in general to ritual, which I will argue is an aspect of religion that is centrally involved in the expression of values. My second strategy is a more specialized anthropological one, and involves developing my theoretical argument about value pluralism and ritual not through an analysis of the religious situation in Brazil or in any other large, religiously and culturally diverse nation state, but rather in a very small Papua New Guinea community in which everyone insists that they are members of the same religion and where I happen to have carried out anthropological fieldwork. Toward the end of the paper, once I have worked through the kind of analysis of pluralism I am proposing in this Papua New Guinea setting, I will try to bring my account back to more familiar social terrain for the discussion of religious pluralism, but that is not where I will start.

My intention in implementing these two strategies - redefining the problem of religious pluralism and enlarging the range of places in which it might make sense to study it - is not to displace or discredit more usual ways of discussing this topic. I have no interest in doing this, nor would I have the expertise needed to bring it off successfully. I simply want to suggest another angle from which it might make sense to look at problems of pluralism. This is not, then, a critical intervention into the existing discussion of religious pluralism. At best, it hopes simply to be a suggestive and perhaps somewhat novel one. With this in mind, we can start with what it might mean to set aside religious pluralism as it is usually understood in favor of a focus on value pluralism.

\section{FROM RELIGIOUS PLURALISM TO VALUE PLURALISM}

From the vantage point of my fairly rough understanding of current discussions on religious pluralism, they appear to focus primarily on relations between relatively bounded religious traditions, relations that persons with different religious identities have with these traditions and with each other, and relations of both religious traditions and of religious people with the state. Issues of the peaceful or violent nature of the relations between religions and between religions and the state, and of the exclusivity or openness of religious identities, as well as those of tolerance or strict control of movement between religions on the part of the state, are central to these discussions. Although everyone knows these matters have never been simple, at least in the Euro-American literature I am 
most familiar with there does seem to be a background assumption, dating back at least to the political framework initially laid down at the Peace of Westphalia and in social science to theories like those of Durkheim, that things work most easily where politically/socially bounded groups of people adhere to a single religion. It is when this condition is not met that the problems that are at the heart of pluralist debate - problems of how religious boundaries are constructed, relations between religious groups are managed, and movements between them are regulated - come to the fore. Taken in the most abstract terms, these are always questions about how social units are defined and how they and their members relate to one another.

At this very abstract level, discussions of religious pluralism and those of value pluralism look very different. This is why shifting from one of these frameworks to the other when considering religious diversity holds some potential interest. But before I lay out these differences, let me say a little bit about what I mean by values and by value pluralism. I take values to be those ends that are culturally defined as worth orienting action toward. Scholars sometimes emphasize the importance of cultural definition in this scheme by saying that values are "desirable" ends and not merely ones a person might happen to desire at any given moment (Kluckhohn 1962[1951]: 395). When people are conscious of their values, this is to say, there is a kind of second order thinking involved: not only do I want X, but I understand that it is good to want X. To get a feel for what values as I am defining them are like, think of the social formation that shapes conduct in international academic settings such as conferences. Two of the values in play in such settings are a general value of politeness and one of truthfulness and honesty. In the academic settings in which we spend much of our time, we sometimes want to be polite, and we feel that is it good to do so, and we sometimes want to be honest, and feel that it is good to behave in this way as well. There are other values that shape our behavior in academic settings, of course - values such as those of intelligence and success - but the two rather humble examples of honesty and politeness may help give a sense of what I mean by values in this paper.

The co-existence of the values of honesty and politeness in academic settings allows me to make two other important points about values. The first of these points is that in all social formations there are a number of values in play. I cannot take the time to argue here, as I have elsewhere, that there are theoretical reasons why it must be so that every social formation contains a multiplicity of values, reasons I take from the work of the anthropologist Louis Dumont (Robbins 2013). But I hope that by 
considering the social settings you know well you might be able to take it as self-evidently true that this is the case, as I have just shown in very broad terms that it is for academic settings like conferences. The second point I want to make with reference to my example of the existence of the academic values of politeness and honesty is that in many cases some of the values that are relevant to a given social situation at least appear to those involved in them to be in conflict with one another. Sometimes we feel that being polite in an academic context means forgoing a chance to be honest, as, for example, when we politely tell someone we very much liked a paper they just presented when in fact we did not. And sometimes we feel that being honest means forgoing a chance to be polite, as when we tell someone we very much disliked their paper, despite knowing that this will upset them. In our second order reflection on our desires, we find that it is good to be both honest and polite - both are values but in fact there are many situations in which we can realize only one of these values and must let the other go.

I have noted that more than one value exists in many social formations and that actors often feel some of these values to be in conflict in order to help further clarify what I mean by value pluralism. The basic fact that all societies contain more than one value is not in itself what scholars mean when they talk about value pluralism. Value pluralism is not, that is to say, simply the claim that people everywhere live with more than one value. From now on, let's call that claim about there everywhere being more than one value a claim about "value multiplicity." We can then use "value pluralism," as opposed to value multiplicity, to refer not simply to the existence of multiple values, but to issues involving the relationships that hold between these values. One way to think about these relationships is to suggest that the values of a society work smoothly with one another. In this view, which is known in philosophy as the "monist" position, values are, as Plaw (2004: 109) puts it in passing, "harmoniously integrated." This harmony can come about because, as Galston (2002: 6) phrases matters, there is "a comprehensive hierarchy or ordering among goods," or, as in Dworkin's (2011: 10) major recent formulation of the monist position, each important value supports the realization of all others, or, finally, because all the values we might recognize as existing in fact reduce to one "supervalue," such as pleasure, because each gains its own value by contributing to the realization of that supervalue (Chang 2001). Value pluralists oppose themselves to this monist position, asserting that values often conflict with one another, such that pursuing one means failing to pursue the other. 
Isaiah Berlin and Max Weber are well known pluralists (Lassman 2004). Berlin (1998: 239) has famously given voice to this position by stating that:

If, as I believe, the ends of men are many, and not all of them are in principle compatible with each other, then the possibility of conflict - and of tragedy - can never be wholly eliminated from human life, either personal or social. The necessity of choosing between absolute claims is then an inescapable characteristic of the human condition.

In Weber's (1946: 147) well-known phrasing, the pluralist position rests on the claim that "the various value spheres [or values] of the world stand in irreconcilable conflict with each other." For pluralists, there is no way, or at least no legitimate, non-totalitarian way, in which value monism can be achieved such that the plurality of existing values does not lead to the possibility of conflict between them.

We can return to the academic values of politeness and honesty to illustrate the differences between monism and pluralism. Monist's would argue that there are ways to reconcile the conflicts many people feel between these two values. It might be the case that if one understands the academic value of honesty correctly - such that, say, it is only acted upon after extensive self-scrutiny to make sure one has not allowed personal feelings of competitiveness or aggression to shape ones determination of what is true - then it is always polite to speak honestly, since acting in this way always has the potential to lead to constructive outcomes for the person to whom one is speaking. Or, taking a different monist tack, it is possible to argue that either the value of politeness or that of truthfulness is always more highly valued in academic settings. If it is the case that that, for example, it is always better to be honest than polite in such settings, then there would never be legitimate conflict concerning which value to apply when a person can only apply one of them. Pluralists, as we should by now expect, do not find these monist arguments plausible. Instead, they hold that there are situations in which choices have to be made between politeness and honesty that will necessarily result in realizing less of one or the other value, despite the fact that it would be desirable to realize both as fully as possible. For pluralists, there are a number of worthy values that conflict in this way (justice and mercy, liberty and equality, and freedom and security are some important pairs that scholars often put forward by way of illustration these days). The need to make choices between them that result in the loss of some value - choices Berlin refers to as "tragic" in the quotation above - is thus an unavoidable aspect of human life. 
Although Weber is an early sociological entrant into the debate between monists and pluralists, it is philosophers who have more recently been at the center of these discussions. They conduct them in quite general terms and aim for universally applicable normative conclusions that would support either a strictly monist or a strictly pluralist position. As an anthropologist, I would like to approach the issues of value monism and pluralism from a different point of view: one that asks how it is that people live with the multiplicity of values that confront them within the social formations in which they conduct their lives. Examining matters of value multiplicity from this point of view, I want to suggest that people in some contexts strive to work out monist solutions to the problems presented by value multiplicity, while in other contexts they find themselves content to live with the need to make tragic choices between values. Furthermore, people can also experience a push and pull between monist and pluralist tendencies within themselves. If one wants to study values in social life, on this model one key way to do so is to examine how the struggle between monist and pluralist tendencies is carried out in individual lives in a given social formation. What I am calling for here is a study of religious pluralism in precisely these terms: as a study of how value multiplicity shapes the way people lead religious lives in a given social formation.

This reformulation of the problem of the study of religious diversity in terms of value multiplicity puts me finally in a position to explain how this approach differs from those framed in terms of religious pluralism. When religious pluralism is the framework, recall that the key issues are the ways religious groups and personal identities are defined and the ways relations between them are negotiated. There is also a background assumption that the simplest, maybe even the most "natural" state is one in which each person and each clearly defined group of people has only one religion. From the point of view of the study of value multiplicity, however, group boundaries and identities are not key concerns. It is assumed that people everywhere, regardless of the groups they belong to and the identities they hold, confront the problem of contending with a multiplicity of values that can guide their actions. There is no primitive, Edenic state from which the condition of value multiplicity can be judged a fallen one. Moreover, boundary crossing and identity switching are no longer major issues. Instead, our main scholarly concern becomes exploring how people manage the relations between the values they hold as they move between situations and life-stages that push them sometimes towards 
kinds of monism and at other times toward kinds of pluralism. For the rest of this paper, I want to look at problems of how people manage religious diversity in these terms.

\section{FROM RELIGION TO RITUAL}

Having shifted our focus from religious pluralism to value pluralism, I now want to make my second shift in emphasis: from religion broadly conceived to ritual. My primary reason for doing this is that in worlds in which there are always multiple values in play, I think rituals are one of the places where people are able to encounter single values clearly expressed and to act on them one at a time. To put this in another way, during the rush of social life, people find themselves orienting toward many different values nearly simultaneously and are often unable to realize any one of them very fully. Think again of academic conferences where one is sometimes polite and sometimes honest, often moving between realizing one of these values and then the other in the same interaction, and finishes the day neither having been a fully polite nor a fully honest person. It is in ritual, in contrast to daily life, that I want to argue that people come closest to realizing single values fully. At the end of an academic lecture, for example, in some places one engages in a ritual of applauding the speaker. In that act, one accomplishes politeness with a clarity and completeness one rarely achieves at other times in a conference setting. The ability to engage with one value at a time in this way is, I am arguing, a large part of what makes rituals appealing to those who participate in them.

I base my argument that rituals allow people to encounter and realize single values in unusually complete form on two branches of ritual studies that I will call the representational and the performative streams respectively. I am not able to provide a full review of ritual theory here, and in any case I think the basic ideas I am drawing on are so widely known as to need fairly little introduction. Suffice it to say that representational theories are those that focus on the ability ritual has to represent aspects of the social world in relatively unique ways. To give three brief examples, we can begin by considering Roberto DaMatta's $(1991: 24,25)$ argument that rituals provide a "dramatization of certain elements, values, ideologies, and relationships in a society" in a way that brings to light aspects of people's social lives "normally submerged by everyday routines, interests, indifferences, and some other similar complications.” Bruce Kapferer (2006: 673) has recently argued for a similar view 
of ritual as constituting a space of virtuality which "allows people to break free from the constraints or determinations of everyday life" not in order to leave everyday life and its concerns behind, but to slow "down its flux and speed" (p. 676) so they can examine and perhaps transform its elements. And finally, we can take note of Jonathan Z. Smith's (1982: 63) definition of ritual as "a means of performing the way things ought to be in conscious tension to the way things are in such a way that this ritualized perfection is recollected in the ordinary, uncontrolled course of things." As these brief accounts demonstrate, DaMatta, Kapferer and Smith all suggest that rituals accomplish a kind of highlighting and perhaps we might say perfecting of social representations that people often only vaguely or incompletely apprehend in social life (see also Valeri 1985: 244-245). To this kind of argument, I would add only the specification, already anticipated explicitly by DaMatta, that one kind of representation rituals routinely present in clear or perfected form is that of values. Rituals allow people, that is, to suspend the complex relations that hold between the many values they confront in everyday life, and instead experience what it is like to apprehend and realize a single value fully.

While representational theories of ritual help us recognize that rituals present values in the ways I have discussed, it is performative theories of ritual, of which Roy Rappaport's (1999) is probably the currently most influential, that explain how they are able do this. Performative theories of ritual, to simplify matters significantly, hold that like all performative acts rituals bring things about or get things done by the simple fact of their performance. Because this is so, those who participate in a ritual commit themselves to intending to accomplish whatever the ritual is understood to performatively bring about. In making such commitments to realizing ritual outcomes, I am suggesting that people also commit to realizing the values these outcomes embody. If we participate in a healing rite, for example, we commit to the notion that it is valuable, or good, for the patient for whom the rite is held to be healed. Because each ritual, as a performative action, commits those who participate in it to the achievement of a particular goal, each of them also at least presupposes and often also explicitly expresses the value that this goal realizes. This is why rituals provide opportunities to realize single values quite fully and also tend to offer such clear representations of the values they express.

I am now finally in a position to explain why I am choosing to focus on rituals rather than on religions in my discussion of pluralism from the point of view of values. Some religions, like the rituals they contain, may also aim at the realization of a single value, but I do not think they routinely achieve this 
aim as often as rituals do. Perhaps because religions are charged with being applicable to many or all areas of social life, even those that make an effort to focus clearly on a single value end up reflecting the value multiplicity that marks social life as a whole. ${ }^{1}$ Rituals, by contrast, can be more specialized. They can work on one value at a time. This is one reason why in Brazil and in the Papua New Guinea case I will discuss and in many other places as well people find it possible to belong to a single religion but also to participate in rituals that fall outside of it. When they want to realize in a strong form a value not well represented in their own religious tradition, it is rituals from elsewhere that allow them to do so. This is also the reason I think it can be useful, when focusing on how people live with a multiplicity of values, at least in some cases to discuss ritual pluralism rather than religious pluralism more generally.

\section{RITUAL PLURALISM AND VALUES IN A PAPUA NEW GUINEA SOCIETY}

It is at this point in my paper that I want to deploy my final strategy for redefining our usual ways of approaching religious pluralism. Having shifted from religious pluralism to value multiplicity, and from religion in general to ritual, I now want to shift our focus from the co-existence of more or less distinct religious traditions in large nation-states to an examination of some aspects of the religious lives of the Urapmin people of Papua New Guinea. I will argue that even in the tiny Urapmin community, in which everyone is a devout charismatic Christian, there exists a ritual pluralism that reflects the multiplicity of values that exists in Urapmin society and that allows people to explore and manage the relationships that hold between these values.

The Urapmin are a group of roughly 400 people living in the West Sepik Province of Papua New Guinea. Remote even by Papua New Guinea standards, the Urapmin were never directly missionized by westerners, though they became familiar with many of the tenets of Christianity by sending out a number of young people to study with Baptist missionaries who came to work with their neighbors in the 1960s. Then, in the late 1970s, a Protestant charismatic revival movement spread throughout Papua New Guinea. When it reached Urapmin territory in 1977, the entire adult population

1 Its possible to speculate that this is also why religions seem almost always to contain a number of distinct rituals, which allow them to realize a range of different values that are relevant to their members. 
converted to charismatic Christianity. By 1978, Urapmin was in its own self-understanding a completely Christian community. Since that time, working toward Christian salvation has been the dominant theme of Urapmin public life, and of most people's private lives as well. I have described the conversion of the Urapmin in great detail elsewhere and, more crucially for my discussion here, I have argued that Urapmin Christianity defines salvation as ultimately an individual matter - something each person has to work out for him/herself (Robbins 2004a). In Urapmin, Christianity thus promotes a particular brand of individualism as the most important value one can dedicate oneself to realizing.

At the same time as the Urapmin have come to take a version of Christian individualism as their most important religious value, much of their social life continues to be shaped by the value that was traditionally paramount in the community. This is the value of what I have called "relationalism" - a value that defines the creation and maintenance of relationships as the most important goal one can work toward achieving (Robbins 2004a). In contemporary Urapmin life, people often find themselves caught between realizing the value of individualism, which in their understanding requires something of a withdrawal from social life in order to avoid sin, or realizing the value of relationalism, which requires sustained social engagement directed toward bringing others into relationships and keeping them involved in relationships once one has connected with them. People's failure to realize either value fully most of the time leaves them in a state of moral frustration, a frustration they describe in Christian terms as a strongly felt sense of their own sinfulness. This feeling of moral frustration well illustrates my point that in daily life people generally find their actions to fall short of fully realizing any one of the values they hold to be most important.

Yet even as most Urapmin find it difficult to realize any of their values very fully in daily life, there are ritual settings in which they are able to do so. To make this point, I want to consider two of the rituals Urapmin find most dramatic and important - a Christian ritual called a "Spirit disco" (Spirit disko $^{2}$ and a traditional one referred to as a "pig sacrifice" (kang anfukeleng). These two rituals make a nice pair in terms of the argument of this paper, for the Spirit disco is an unusually complete realization of the value of individualism, while the pig sacrifice fully realizes the value of relationalism.

2 In this article, terms given in Tok Pisin, the most common lingua franca of Papua New Guinea, are underlined, while those in the Urap language are given in italics. 
I will begin with the Spirit disco, a key rite of Urapmin Christianity. Urapmin prepare themselves for salvation by participating in a wide range of rituals, from attending Church services, to studying the bible, to praying regularly throughout the day. The goals of all Christian ritual activities are to strengthen a person's heart (aget - the seat of all thought and feeling) so it will not be tempted to answer the call of sin and to cleanse the heart of the sins it has committed. Understood as linked rites leading to the creation of an individual self that is prepared for Jesus' return, many Christian rituals can be seen to point to the performance of the Spirit disco, a ritual the Urapmin undertake infrequently relative to most other Christian rites. The Spirit disco stands at the apex of Urapmin ritual life because it most dramatically and completely accomplishes a goal other Christian rituals contribute toward realizing but do not themselves wholly bring about in such spectacular fashion: it renders all its participants individually free of sin and ready to be taken by Jesus to heaven should the Second Coming transpire near to the time of its conclusion. The Spirit disco does this by removing the residues of committed sins from the hearts of those who take part in it.

Spirit discos are circular dances performed at night inside the church. Most members of the church attend when one is held. During the dance, some of the dancers become possessed by the Holy Spirit. Once this happens, they begin to flail wildly and will be "controlled" by other dancers who hold them and do their best to prevent them from hurting themselves or others. During a successful dance, several people will become possessed in this way for up to an hour. At the height of the rite, the scene inside the church can be chaotic, with all of the possessed people careening unpredictably around the room as others struggle to keep up the circular pattern of the dance. Eventually, the Spirit will leave the possessed dancers one by one. When the Spirit leaves a dancer, he/she collapses on the floor, completely limp, unconscious, and, as the Urapmin see it, at peace. After possession, people will lie on the church floor in this state for some time as the dancers slow down and eventually stop. Participants remain with those who were once possessed until the regain normal consciousness. Then everyone will pray together and the ritual ends.

In Urapmin understanding, the violence of possession during the Spirit disco is due to a battle within the possessed person's heart between the Holy Spirit and his/her sins. The conclusion of possession happens when the Spirit finally succeeds in "throwing" the person's sins out of his/her body - this cleansing the person of $\sin$ is the performative goal the ritual accomplishes. To prepare to reach 
this goal, before commencing the Spirit Disco all participants must confess their sins to a pastor or deacon who will pray over them and tell God that the sins have been given to Him. But it is only during the Spirit disco and the possession that is central to it that the sins are finally removed from the body. This leaves the person ready for salvation. As the Urapmin see it, the previously possessed person lying still and alone on the Church floor represents the full realization of the saved individual. As one person once crystallized the general Urapmin understanding for me, "once people leave the church building they will start sinning again" - they will, to put it otherwise, be caught again in the sinful snares of trying to realize a range of different values at once. For this reason, it is only at the climactic moment at the end of the Spirit disco that one can be sure of one's own or someone else's salvation. It is thus the only time in Urapmin social life that the value of becoming an individual worthy of salvation is fully realized. ${ }^{3}$ The Spirit disco is, then, an example of the value of Urapmin Christian individualism worked out in its fullest form.

If the Spirit disco stands as the capstone of a wide range of Christian rituals, pig sacrifice in Urapmin is a more singular institution, with no links to other rites the Urapmin practice. In fact, pig sacrifice is the only "traditional" ritual the Urapmin still enact. As I have discussed elsewhere, many Urapmin are for this reason ambivalent about performing it and question whether they are led to do so by the promptings of evil spirits (sinik mafak) (Robbins 2007). But it is also true that the community has been unable to give it up. My argument here is that this is so because pig sacrifice is a key example of the full realization of the value of relationalism that, despite the Christian promotion of individualism, still remains important in Urapmin people's lives.

Pig sacrifices are offered to nature spirits (motobil) whom the Urapmin formerly believed owned every significant part of their natural environment: land, major trees, rivers, large rocks, and the game animals people hunt. In the past, the nature spirits allowed Urapmin people to use these resources provided they observed various taboos the spirits who owned them put in place. Among other things, these taboos forbid the Urapmin from talking loudly or laughing while they hunted and

3 In the terms I have been using throughout this paper, in many other Christian rituals, people both encounter the value of living sinlessly in order to be saved as individuals, and they succeed in working unambiguously toward this goal - a kind of work it is difficult to accomplish in daily life - but it is only in the Spirit disco that they can be said to fully achieve this end. 
gardened, lest they offend the spirits. If the Urapmin offended the spirits by violating these taboos, the spirits would "hold" (kutalfugumin) them and make them sick. As Christians, Urapmin now say that God created and owns everything and that he wants people to use the resources he provides. There are no more taboos. Instead, they say, now is "free time" (fri taim), and people should in principle be able to use the earth's bounty without fear of the nature spirits' retribution.

Yet even as the spirits have lost their position as the original owners of all of the resources of the Urapmin landscape, the Urapmin continue to recognize their existence. As in the past, whenever people become sick, it is assumed that they have disturbed the spirits in some way. Generally, friends and family respond to sickness by praying to God to remove the offending spirit from the sick person, and sometimes they engage Christian ritual specialists to help them in this endeavor. Yet when illnesses linger, especially in children (who unlike adults can die from illness caused by nature spirits), people will sacrifice a pig to them, asking them to take the "smell" (tang) of the pig and let go of their human victim. This gift of a pig to a spirit is a very full expression of Urapmin relationalism - which is similarly elaborated through gift exchange in many other ritual contexts - because it realizes this value in the face of the nature spirits' general failure to do their part in the making and maintaining of relations. Unlike people, spirits do not give generously. They hedge their gifts with taboos, and their generosity is unreliable. Mostly they would prefer to be left alone. It is by virtue of realizing the value of relationalism in connection with the spirits, and this despite the spirits' lack of strong commitment to this value, that pig sacrifice stands as a key performance of relationalism in Urapmin culture. By continuing to undertake this ritual, despite their fears that it is sinful in Christian terms, the Urapmin realize a thoroughly worked out version of the relationalism that continues to figure in so many areas of their lives.

I want to pause at this point in my discussion of the relationship between ritual and values in Urapmin to note how different my discussion of the Spirit disco and the pig sacrifice would look if I were approaching it with the tools we usually use to analyze religious pluralism. If I were to approach it with these tools, I would begin by focusing on the fact that these two rites can be seen as belonging to two distinct religious traditions that are in conflict with one another. The Urapmin themselves sometimes talk about the two rites in something like these terms. They note that pig sacrifice is not a Christian custom. Instead, it is one of the traditions of the ancestors (alowol imi kukup). And as I have 
already noted, as Christians they worry that it is a sinful practice that they might be better off not practicing at all. But from an outside analyst's point of view, the most noteworthy fact about the ritual situation in Urapmin is that people do practice both of these rites. An analysis of this fact from the point of view of religious pluralism would focus on the conflict the practice of pig sacrifice engenders in this Christian community. But in fact, the conflict surrounding pig sacrifice is fairly low-grade and intermittent and for this reason it does not seem to demand the bulk of our analytic intention. An analysis from the point of view of the ritual management of value multiplicity thus usefully leads us away from the temptation to devote too much attention to this conflict, and instead encourages us to explore what both rituals tell us about the multiplicity of values that shape Urapmin life. It leads us, that is to say, to ask different kinds of questions than we would if we were carrying out an analysis of religious pluralism. It is the usefulness of these kinds of questions I am working to establish in this paper.

I hope it might count as further evidence of the usefulness of the approach to ritual and value multiplicity that I am laying out here that it also sheds some light on an aspect of ritual diversity that rarely receives sustained attention: the phenomena of ritual innovations that fail. Two examples of such ritual failure in Urapmin can help us see how a consideration of ritual in relation to value pluralism can also help us trace the limits of value multiplicity in a given social formation by allowing us to catch glimpses of values that people wholly reject.

The first failed ritual I want to explore involves one Urapmin man's attempt to redesign traditional death rites. Traditional death rituals in Urapmin have a number of parts, which include gifts of food form those who lived with the deceased to his or her other relations, who in good relationalist fashion take the food they have received home to share with those among whom they live. The rites also involve the exchange of exactly equivalent goods between those who lived with the deceased and his or her other relatives. ${ }^{4}$ Exchange rituals of various kinds that, like this one, revolve around the give and take of exactly equivalent goods are relatively frequent performances of the value of relationalism. The whole complex of rites around death is thus taken up with realizing relationalism in one of its fullest forms, an appropriate response to the way death by its nature threatens to destroy the kinds of relational networks the Urapmin so highly value by removing one of its nodes.

4 See Robbins 1999 for a fuller discussion of these exchanges.

Debates do NER, Porto Alegre, ANO 15, N. 26, JUL/DEZ.2014. 
The innovative death rite I want to discuss dispenses with the emphasis on the value of relationalism that is so much a part of traditional death rituals. To understand this new rite, its development needs to be understood in relation to remoteness of the Urapmin territory. The community has no electricity, road, or airstrip, and there is very little local involvement with the cash economy. But Urapmin is located five days walk away from Ok Tedi, a very large gold and copper mine that is situated in the town of Tabubil. Since the mine opened in the 1980s, many Urapmin men have worked there for short stints as laborers. And one Urapmin man whom I will call Docsi is unique for having lived in Tabubil for over 15 years. Although he has remained a low paid laborer who lives in a squatter settlement (rather than in the more prestigious company housing), he is the Urapmin person with the single greatest experience of the market economy and the more modern or "white" world of Tabubil. For this and other reasons, he is widely respected in Urapmin.

When Docsi's elderly parents died within days of each other, he came home to Urapmin and announced that he was going to perform a new kind of death ritual for them. The ritual he had in mind was patterned after how food is served and eaten in the mess hall at the mine. He had the younger men of his village built a serving counter along which people would walk and receive individual-sized portions of food at different stops - a serving of cooked taro at one stop, of pig meat at another, and of greens further down the line. Then, once everyone had filled their plates, Docsi planned that they would all sit around his parents' village and eat, just as everyone eats together in the Ok Tedi mess hall. As far as I ever learned, this would be the entirety of the ritual - there would be no accompanying exchange of exactly equivalent goods.

Docsi's authority was such that people were initially excited about the proposed new rite. On the day of the ritual itself, the younger men of Docsi's parents' village manned the serving line and everyone walked along it with their individual plates and collected their food. Then they sat down. But the scene was very quiet, and it appeared no one was comfortable eating together publicly, as if in a cafeteria. In traditional feasts, one always takes the food away, redistributes most of it, and then eats the rest in the privacy of one's own house. The idea of eating individual portions oneself in public was very shameful (fitom) for people. One senior man eventually stood up and walked off with his plate in the direction of home. Others quickly followed suit, and soon the village was empty. The innovative death ritual had been an utter failure. 
In analyzing the failure of the new rite, its important to realize that it had every chance to succeed. Urapmin generally find anything new and connected with what they call the "white" world to have some appeal, and everyone in the community respected Docsi as an important local representative of that world. The rite failed not because it was new, but rather because it did not realize to any extent the value of relationalism of which traditional death rites provide such powerful enactments- gifts were one way, given piecemeal by young people of little standing, and neither redistribution nor reciprocation was part of the ritual plan. Nor was the ritual a robust representation of the newer value of Christian individualism, for it made no contribution toward the Christian salvation of those who participated as individual consumers of Docsi's one-way gift of food. Lacking in the crisp, full realization of a single value that defines successful rituals, it solicited in practice little positive attention from the Urapmin, and no commitment at all. Quickly forgotten, it never came to serve as a way of realizing any particular end one might justly want to pursue.

The second failed ritual I want to discuss has to this point failed in a different sense than Docsi's new death ritual. Though people sometimes talk about this rite and how they would go about performing it, they have never brought themselves to the point of actually carrying it out. Docsi's rite did generate enough interest to warrant a performance, though one suspects this had as much to do with Docsi's high standing in the community as with people's excitement about the potential of the rite itself. The ritual I turn to exists only as an occasional topic of conversation, never as a project into which people pour any sustained energy.

The ritual in question is a Christian one that would rid key parts of the Urapmin landscape of all nature spirits, allowing the Urapmin to use the resources to which the spirits attached themselves with no fear of contracting the illnesses that spirits cause as reprisals for taboo violation. This rite of spiritual removal, for which the Urapmin have not settled on a name, is in some respects similar to rites they do regularly perform. ${ }^{5}$ When people first become ill, ritual specialists known as "Spirit women" (Spirit meri) are called in. These Spirit women become possessed by the Holy Spirit, who shows them which nature spirit is causing the illness. They then pray with God's power to command the nature

5 Both the rites the Urapmin do perform and the ones they talk about but as yet do not undertake are very similar to globally widely diffused kinds of charismatic-Pentecostal rituals associated with what is known as "spiritual warfare." The Urapmin, however, do not refer to it using these terms (I discuss the history of the globally diffused form and the Urapmin engagement with it in detail in Robbins 2012). 
spirit to let go of its victim and they ask God to bind the spirit far from Urapmin territory, so it cannot afflict the patient or other people in the future. It is only in those rare cases where repeated attempts at such Spiritual healing over time have failed to bring about an improvement in the patient's condition that Urapmin resort to the pig sacrifice rituals that I discussed earlier. Treatment by Spirit women is far more common, and it is the routine way of handling illness in Urapmin.

Like the treatments for illness performed by Spirit women, the ritual of spiritual removal the Urapmin sometimes discuss but never undertake would involve seeking God's help to remove nature spirits from Urapmin territory. But it would do so on a much grander scale than the treatment of afflicted individuals. As the Urapmin imagine this rite, it would unfold as a number of Spirit women worked together to clear all of the nature spirits out of areas of the Urapmin territory they densely inhabit. This would include formerly sacred (taboo - awem) spaces, other spaces the Urapmin hope might be used in the future for intense resource extraction such as gold mining (there has been some prospecting by mining companies on their land), and villages in which many people have become ill.

Evan as the basic pattern of these imagined rituals has much in common with that of the regularly practiced healing rites of the Spirit women, it is important to note that the rituals have markedly different ends. Healing treatments aim to redress the illnesses of single individuals that they have contracted by disregarding the relational demands of the nature spirits. In successful cases, the patient is returned to living a normal Urapmin life, one in which he/she will have to balance the realization of both relational and individualist values. The nameless rite, by contrast, aims not to redress past conflicts between people and nature spirits, but rather to allow all Urapmin to completely disregard the relational claims nature spirits currently make (even if illegitimately, from a Christian point of view). As was the case with Docsi's new funeral rite, if successful this rite also makes no contribution to people's efforts to realize their Christian individualist projects of freeing themselves from sin. Instead, it simply liberates them to exploit the world around them as fully as they might like in a frenzy of uncontrolled desire and consumption, an outcome that is for the Urapmin a potent image of an undesirable, even sinful, kind of individualism. In this respect, this rite fails because it realizes in full terms something that is disvalued. As such, it bears discussion among the Urapmin for the fantasies 
of unfettered individual consumption it brings to the surface, but it does not solicit performative engagement. ${ }^{6}$

Having discussed two rituals that are important in Urapmin life, as well as two more that have failed to gain a foothold there, I hope to have demonstrated the way in which ritual diversity in Urapmin maps the existence of a number of values and disvalues in the community. As Urapmin perform Spirit discos and pig sacrifices, and as they try out or imagine new kinds of rites like cafeteria style death rituals that promote individual consumption and rites of spirit removal that promote an unfettered use of community resources without regard for the relational entailments such use usually brings with it, I am suggesting that they are also experience what it is like to realize these different values in relatively full form. And as they work out ways of distributing their ritual energies, practicing some rites more than others and letting some rites fall by the wayside, they are negotiating the relationships between the different, and in the cases I have discussed conflicting, values that clamor for their attention. If standard analyses of religious pluralism allow us to explore how social conflicts between adherents of different religions come about or are sometimes avoided, it is my hope that the analysis of value multiplicity and its ritual expression and management might allow us to study the often quieter but no less important ways people must reckon with the multiplicity of values that they all face as they make their ways through life.

\section{CONCLUSION}

When I first introduced the notion of values in this paper, I laid out monism and pluralism as two ways values might relate to one another. Moving on to the study of rituals, which I argued allow people to realize one value at a time, I took the existence of multiple values as a problem all people have to face, but I set aside a focus on the monist or pluralist relations between values themselves. In offering some concluding remarks, I want to return to the issue of monist and pluralist relations

6 In this respect, the nameless spirit removal rite is something of the inverse of the pig sacrifice. The pig sacrifice realizes the important value of relationalism. Even though this is a value the conflicts with the Christian value of individualism, its continued importance in Urapmin lives renders the pig sacrifice a ritual the Urapmin cannot give up, no matter how much they talk about doing so. The nameless rite of nature spirit removal speaks for a disvalue of unfettered consumerist individualism, and as such the Urapmin cannot succeed in practicing it, no matter how much they talk about doing so. 
between values as a way of also returning to some issues at the heart of more orthodox studies of religious pluralism.

We can recall that monism refers to a situation in which values work harmoniously together, either because they exist in a clear hierarchy, or all promote one overarching value, or each supports the realization of all others. In contrast to monism, pluralism describes a situation in which values conflict in irresolvable ways that lead people to have to make tragic choices between them. I argued that from an anthropological point of view the most important questions about values are not those concerning whether monism or pluralism is the right account of how they relate to one another, but rather the ones that ask how people shift between more monist and more pluralist contexts throughout their social lives and also how they contend with tendencies within themselves that push them sometimes to work toward realizing monist relations between their values and at other times to accept in pluralist fashion that some of the value conflicts they confront allow of no easy, non-tragic resolution. One task for anthropology, I suggested, is to study how these tensions between monism and pluralism work out in concrete social formations and in the lives of the people who live within them.

In order to round out the picture I have been offering of how we might carry out such research, I want to return now from the level of ritual analysis to talking about religions more broadly conceived. Rituals, as realizations of single values at a time, all tend toward a kind of situated monism, at least in the course of their performance. But religions can vary greatly in the extent to which the push for monist or pluralist understandings of the relations between values. Pentecostalism and other kinds of religions we tend to see as exhibiting more sectarian dynamics are very much at the monist end of the continuum. Focused intensely on individual salvation, Classical Pentecostals find themselves comfortable condemning all other values and the rituals that represent them. Indeed, Pentecostalism stages its monism quite explicitly because, as is well known, it tends to preserve the spirits that represent the values it rejects so that it can continue to ritually enact their rejection (Robbins 2004b reviews this literature). We have seen that the healing rites of Urapmin charismatic Christianity do this with the nature spirits that represent the value of relationalism that remains important in their social formation. Yet even within the broad Pentecostal tradition, we see variation in how strongly its various branches promote a strictly monist view of values. Faith or Prosperity Gospel churches, for example, have made their peace with the individualist values of the market, and they celebrate them ritually 
alongside their celebration of individual salvation - a stance that often leads other, more monist, Pentecostal churches to critique them as violently as they do other representatives of values that are not their own. Looking beyond Pentecostalism, we can note that other religions tend to be open to an even wider pluralism than the prosperity gospel churches. Catholicism appears often to be open to juggling more than one value, as do some kinds of Buddhism in Southeast Asia (Ames 1964). Both of these traditions are adept at either absorbing folk rites that realize values other than their own most prominent ones, or at allowing people without censure to participate in the rituals of other traditions so they can realize the values those rituals represent. Given that there is such variation in the extent to which any given religion promotes monism or pluralism, a future goal for the study of religious pluralism from the point of view of value pluralism might be that of figuring out when more monist kinds of religions flourish and when more pluralist ones do, and why in some contexts both co-exist in seemingly stable tension. I think that in some respects this is what scholars of religious pluralism are already in fact doing, even if not quite in these terms. My hope in this paper has been that by approaching these questions from the novel angle of values, and by offering some suggestions about how ritual life fits into the picture, I may have opened up some new avenues for us to pursue as we continue to explore what looks set to remain a crucial topic of investigation in the social science of religion for a long time to come.

This paper is dedicated to the memory of Clara Cristina Jost Mafra, an important contributor to the anthropological study of Christianity, a colleague, and a friend.

\section{REFERENCES}

AMES, Michael M. Magical-Animism and Buddhism: A Structural Analysis of the Sinhalese Religious System. In: HARPER, E. B. Religion in South Asia. Seattle: University of Washington Press, 1964. p. 21-52.

BERLIN, Isaiah. The Proper Study of Mankind: An Anthology of Essays. New York: Farrar, Strauss and Giroux, 1998.

CHANG, Ruth. Value Pluralism. In: SMELSER, N. J.; BALTES, P. B. International Encyclopedia of the Social and Behavioral Sciences.New York: Elsevier, 2001. p. 16139-16145.

DA MATTA, Roberto. Carnivals, Rogues, and Heroes: An Interpretation of the Brazilian Dilemma. Notre Dame: University of Notre Dame Press, 1991.

Debates do NER, Porto Alegre, ANO 15, N. 26, JUL/DEZ.2014. 
DWORKIN, Ronald. Justice for Hedgehogs.Cambridge: Harvard University Press, 2011.

GALSTON, William A. Liberal Pluralism: The Implications of Value Pluralism for Political Theory and Practice. Cambridge: Cambridge University Press, 2002.

KAPFERER, Bruce. Virtuality. In: KREINATH, J.; SNOEK, J.; STAUSBERG, M. Theorizing Rituals: Classical Topics, Theoretical Approaches, Analytical Concepts. Leiden: Brill, 2006. p. 671-684.

KLUCKHOHN, Clyde. Values and Value-Orientations in the Theory of Action: An Exploration in Definition and Classification. In: PARSONS, T.; SHILS, E. A. Toward a General Theory of Action: Theoretical Foundations for the Social Sciences. New York: Harper and Row, 1962 [1951]. p. 388-433.

LASSMAN, Peter. Political Theory in an Age of Disenchantment: The Problem of Value Pluralism: Weber, Berlin, Rawls. Max Weber Studies,v. 4, n. 2, p. 253-271, 2004.

PLATVOET, Jan; VAN DER TOORN, Karel. Ritual Responses to Plurality and Pluralism. In: Pluralism and Identity: Studies in Ritual Behavior. Leiden: E.J. Brill, 1995. p. 3-21

PLAW, Avery. Why Monist Critiques Feed Value Pluralism: Ronald Dworkin's Critique of Isaiah Berlin. Social Theory and Practice,v. 30, n. 1, 2004. p. 105-126.

RAPPAPORT, Roy A. Ritual and Religion in the Making of Humanity. Cambridge: Cambridge University Press, 1999.

ROBBINS, Joel. Becoming Sinners:Christianity and Moral Torment in a Papua New Guinea Society. Berkeley: University of California Press, 2004.

. The Globalization of Pentecostal and Charismatic Christianity. Annual Review of Anthropology, n. 33, 2004. p. 117-143.

. You Can't Talk Behind the Holy Spirit's Back: Christianity and Changing Language Ideologies in a Papua New Guinea Society. In: MAKIHARA, M.; SCHIEFFELIN, B. B. Consequences of Contact: Language Ideologies and Sociocultural Transformations in Pacific Societies. New York: Oxford University Press, 2007. p. 125-139.

. On Enchanting Science and Disenchanting Nature: Spiritual Warfare in North America and Papua New Guinea. In: TUCKER, C. M. Nature, Science, and Religion: Intersections Shaping Society and the Environment. Santa Fé: School for Advance Research Press, 2012. p. 45-64.

. Monism, Pluralism and the Structure of Value Relations: A Dumontian Contribution to the Contemporary Study of Value. Hau: Journal of Ethnographic Theory,v. 3, n. 1, 2013. p. 99-115.

SMITH, Jonathan Zit tell. Imagining Religion: From Babylon to Jonestown. Chicago: University of Chicago Press, 1982.

VALERI, Valerio. Kingship and Sacrifi ce: Ritual and Society in Ancient Hawaii. Chicago: University of Chicago Press, 1985.

WEBER, Max. From Max Weber: Essays in Sociology. New York: Oxford University Press, 1946. 
